\title{
Effect of Zeolite and Foliar Application of Selenium on Growth, Yield and Yield Component of Three Canola Cultivar under Conditions of Late Season Drought Stress
}

\author{
Hossein ZAHEDI ${ }^{1}$, Ghorban NOORMOHAMMADI ${ }^{2}$ ), Amir Hossein SHIRANI \\ RAD $^{3}$, Davood HABIBI ${ }^{4}$, Masoud Mashhadi AKBAR BOOJAR ${ }^{5}$ \\ 1) Islamic Azad University, Science and Research Branch, Tehran, Iran; hzahedi2006@gmail.com (corresponding author) \\ 2) Islamic Azad University, Department of Agronomy, Science and Research Branch, Tehran; Iran \\ 3) Oil Seed Crops Institute, Department of Agronomy, Karaj; Iran \\ 4) Islamic Azad University, Department of Agronomy, Karaj Branch; Iran \\ 5) Tarbiat Moallem University, Department of Biochemistry, ; Iran
}

\begin{abstract}
In order to study effect of zeolite soil application and selenium foliar application on growth, yield and yield components of three canola cultivar under conditions of late season drought stress an experiment was conducted in two growing season in 2006 and 2007. Site study was field of Seed and Plant Improvement Institute, Karaj, Iran. The experimental design was a Randomized Complete Block arrangement in factorial split plot with three replications. Irrigation factors were chosen at two levels, included complete irrigation and irrigation holding at stem elongation stage. Zeolite was used at two levels, non application and 10 ton per hectare. Also selenium was sprayed at three concentrations, 0,15 and $30 \mathrm{gr}$ per liter from sodium selenate. These treatments were randomized in main plots while three canola cultivars ('Zarfam', 'Okapi' and 'Sarigol') were randomized in sub plots. The results showed that, main effects of different irrigation levels have significant effect on all traits and drought stress decreased significantly all traits. Foliar application of selenium had significant and additive effect on plant height, number of pods in plant, number of seeds in pod, seed yield, biological yield, harvest index and oil yield. There was significant difference between zeolite application and non application on all traits except oil percent and harvest index. It was shown that canola cultivars were different in all of studied traits. Comparison of means showed that, four critical traits that is seed yield, biological yield, harvest index and oil yield were affected by experimental treatments. Different cultivars have different responses under unlike conditions inside upon traits. Under different treatment conditions especially drought stress, zeolite and selenium application have positive and significant effect on traits related to yield. In finally, zeolite and selenium application in dry lands that are exposure to late season drought stress can be helpful for yield improvement and prevent of decreasing yield.
\end{abstract}

Keywords: canola, drought stress, selenium, yield and yield component, zeolite

\section{Introduction}

In many region of the world among Iran, drought stress is one of the most important factors that decrease agricultural crop production. Canola (Brassica napus L.) is one of the important oil plants in the world. Late season drought stress and increase of temperature during flowering and seed filling stages decreases canola yield. The results of researchers shown that, in many plants flowering, pollination and seed filling are sensitive stages to drought stress (Thomas et al., 2004; Liu et al., 2004). It's reported that, flowering and primary stages of pod setting are most sensitive stages of canola growth (Hashem et al., 1998). Responses of two canola cultivars to drought stress have been studied by Wright et al. (1995) they shown that, seed yield and oil percentages were strongly affected by drought stress. According to published results, decrease in canola seed yield is due to decrease in yield component include pod number, seed number in pods and 1000 seed weight in response to drought stress. Jensen et al., (1996) showed that complete irrigation during flowering and primary stages of pod development, increases pod number and seed number in pods but average of 1000 seed weight were less affected than seed number in pod. Flowering stage and pod setting are critical stages to drought stress in canola (Rao and Mendham, 1991). Effects of different irrigation regimes at flowering stage on canola has been studied by Deepak, and Wattal (1995) their results showed that water stress decreased significantly seed yield and biological yield. Decrease of biological yield and pod dry matter has been observed in two canola cultivars under conditions of water deficit (Wright, et al., 1998). 
74

In recent year a few of the more commonly used inorganic soil amendments are the porous ceramics, diatomaceous earth and zeolites. Some of the characteristics of these products that potentially make them desirable for improving the properties of soils are the large internal porosity that result in water retention, a uniform particle size distribution that allows them to be easily incorporated and high cation exchange capacity that retains nutrients (Ok et al., 2003). The unique physical and chemical properties of natural zeolites, in combination with their abundance in sedimentary deposits and in rocks derived from volcanic parent materials, have made them useful in many industrial applicators. These properties have spurred their use for agronomic and horticultural applications as well (Dwairi, 1998). Zeolites are natural minerals first discovered in 1756 by Swedish mineralogist, who named the porous minerals from the Greek words meaning "boiling stone" (Mumpton, 1999). They are hydrated alominosilicates, characterized by three dimensional networks of $\mathrm{SiO}_{4}$ and $\mathrm{AlO}_{4}$ tetrahederal, liked by the sharing of all oxygen atoms. The partial substitution of $\mathrm{Si}^{+4}$ by $\mathrm{Al}^{+4}$ lead to an excess of negative charge which is compensated by cations. In structure of natural zeolite the water and cations can be reversibly removed or replaced by other cations (Rehakova et al., 2004). Clinoptilolites are one kind of zeolites which are not the most well known yet, but are one of the most useful zeolites. Extensive deposits clinoptilolite are found in Western United State, Bulgaria, Hungary, Japan, Australia and Iran (Mumpton, 1999). The size of clinoptilolite channels controls the size of the molecules or ions that can pass through them and therefore a zeolite like clinoptilolite can act as a chemical sieve allowing some iones to pass through while blocking others (Mumpton, 1999). Amendment of clinoptilolite zeolite to sandy soils has been reported to lower nitrogen concentration in the leachate and to increase moisture and nutrients in the soil due to increased soil surface area and cation exchange capacity (He et al., 2002). Additionally, clinoptilolite zeolite is a more permanent addition to the root zone, demonstrating good stability in weathering, impact and absorption tests (Ok et al., 2003).

Selenium is an essential trace element for animals and humans (Tapiero et al., 2003) but its role in plants is still unclear (Hartikainen et al., 2000). Most cereal crops and fodder plant are relatively weakly able to absorb selenium, even when grown on soils with higher selenium content (Nowak et al., 2004). Selenium is chemically similar to sulphur, this may cause a non-specific replacement of $S$ by selenium in proteins and other sulphur compounds (Nowak et al., 2004). There are indications that it can also play a positive biological role in higher plants (Germ et al., 2005). Selenium could increase the tolerance of plants to UV-radiation induced oxidative stress, delay senescence, and promote the growth of ageing seedlings (Xue et al., 2001). Results of Pennanen et al. (2002) have showed that plant growth promoted by selenium is due to the increased starch accumulation in chloroplasts. Recently it has been shown that selenium can regulate the water status of plants under conditions of water deficiency and thereby performs its protective effect (Kuznetsov et al., 2003). The goal of this work was to determine the response of three cultivars of canola to combined effect of late season drought stress, soil zeolite application and Se foliar application.

\section{Materials and methods}

This study was conducted at the experimental field of Seed and Plant Improvement Institute (SPII), Karaj, Iran, (35 59' $\mathrm{N}$ latitude, $50^{\circ} 75^{\prime} \mathrm{E}$ longitude and altitudes of $1313 \mathrm{~m}$ ) on three canola cultivar (Brassica napus L. C.V 'Zarfam', 'Okapi' and 'Sarigol'), in the 2006 and 2007 growing season. The yearly average precipitation (30-years long term period) which is mostly concentrated during the autumn and winter months was $244 \mathrm{~mm}$.

Before the beginning of experiment, soil samples were taken to determine the physical and chemical properties. A composite soils sample was collected from depth of 0-30 and 30-60 cm. It was air dried, crushed, and tested for physical and chemical properties. The research fields had a clay loam soil. Details of soil properties are shown in Tab. 1. After plow and disk, plots were prepared. The experimental design was laid out in a Randomized Complete Block with a factorial split plot arrangement of treatments in three replications. The treatments were included; irrigation at two levels, complete (I1) and limited irrigation (I2) at early of stem elongation. Zeolite application at two levels that is $0(\mathrm{Z} 1)$ and 10 ton per hectare $(\mathrm{Z} 2)$ and selenium foliar application at three concentration 0,15 and 30 gr.liter $^{-1}$ as sodium selenate, $S 1, S 2$ and $S 3$, respectively. These treatments were applied on three canola cultivars. According to soil analysis chemical fertilizers and zeolite were distributed on the soil surface and incorporated with the soil in depth of $30 \mathrm{~cm}$. The plots were $5 \mathrm{~m}$ long and consisted of six rows, $0.3 \mathrm{~m}$ apart. Among blocks and main plots, $6 \mathrm{~m}$ and $2.4 \mathrm{~m}$ alley was kept to eliminate all influence of lateral water movement. The canola seeds were disinfected and sown on early of October. The distance between plant rows was $30 \mathrm{~cm}$ and the plant density was around 1,000,000 plants per hectare at sowing time. Irrigation was carried out as similar in all plots until flowering stage. Non stressed plants were irrigated according to $80 \mathrm{~mm}$ evaporation from class A pan evaporation. Weeds were effectively controlled by hand. Selenium foliar application from sodium selenate was carried out in three concentrations $\left(0,15\right.$ and 30 gr.liter $\left.^{-1}\right)$ by engine backpack sprayer at late of stem elongation stage. At of growing season, plant height, number of branches in plant, number of pods in plant, number of seeds in pod, 1000 seed weight, seed yield, oil percentage, oil yield, biological yield and harvest index were measured. To measurement of plant height and number of branches in plant, after eliminating the margin effect 10 plants were randomly harvested 
from middle of each plot and then mean of the traits were registered. Numbers of pod were counted in these plants. Pods of these plants were separated and 30 pods were randomly selected and number of seeds in each pod and 1000 seed weight were calculated. Also, five plants of each plot was sampled and dried in oven at $60^{\circ} \mathrm{C}$ during 72 hours to determine of biological yield. Harvest index and seed yield were calculated too. Oil percentage was estimated by N.M.R and oil yield was calculated via product seed yield in percentage oil.

All data were analyzed from analysis of variance (ANOVA) using the GLM procedure in SAS (SAS Institute, 2002). The assumptions of variance analysis were tested by insuring that the residuals were the random, homogenous, with a normal distribution about a mean of zero. LSMEANS command was used to comparison of means at $\mathrm{P}<0.05$ probability.

\section{Results and discussion}

According to Bartlett test results, $\chi^{2}$ was not significant for all traits therefore the analysis of variance was carried out on base of combined analysis of variance. Combine $F$ significance from analysis of variance of irrigation, zeolite, selenium and cultivar in 2006 and 2007 (Tab. 2) showed that, effect of year was significant in all traits except, number of branches in plant and harvest index. It' was observed that effect of different irrigation levels was significant in all traits. Selenium foliar application had significant effect on plant height, number of pods in plant, number of seeds in pod, seed yield, biological yield, harvest index and oil yield. Affect of zeolite soil application was not significant just on oil percentage and harvest index. Canola cultivars had significant difference among them. The results showed that, often interaction effects among treatments was not significant. Interaction effects among irrigation, selenium, zeolite and cultivars was significant just on seed yield, biological yield, harvest index and oil yield.

Comparisons of main effects are shown in Tab. 3. There are significant differences among first and second year on all traits except, number of branches and harvest index. Oil percentage and biological yield were decreased at second year than first year while in other traits a significant increase was observed.

Limit irrigation during stem elongation stage decreased significantly all traits. Seed yields was lost by $51.81 \%$. This reduction was due to decrease in yield components such as seed weigh, number of seeds in pods number of pods in plant and number of branches in plants. Also there was significant decrease in biological yield by $61.73 \%$ due to decrease of vegetative growth and height. It's known that, decrease in plant height is due to decrease in cell division and assimilates transport. There are many reports about decrease of vegetative growth and plant height under conditions of drought stress (Wright et al., 1995). Increase of plant height is related two phenomenons, increase of nod numbers and increase of inter nods length and these are strongly affected by drought stress (Wright et al., 1995).

Reproductive stage included, stem elongation, flowering, pollination and seed filling are sensitive stages to water stressing (Thomas et al., 2004). Flowering and pod setting stages are susceptible to drought stress in canola (Wright et al., 1995). The results are descriptive of this fact that, flowering and pod setting stages are critical period to water supply and water stress in these period decreases strongly pod number and seed yield. Triboi and Renard (1999) have been reported that, drought stress in canola decreases pod number, also Bouchereau et al (1996) showed that there is positive correlation between seed yield and number of branches and seed yield and seed weigh. In general, suitable water supply at flowering stage and pod development stage increases seed number in pods and increases seed yield (Mendham and Salisbury.1995). Mendham and Salisbury (1995) have reported that sufficient irrigation at first of pod setting stage is very vital for produce of desirable yield; also they have observed water stress occurrence at first of pod growth is effective on pod number while water stress after this stage is effective on seed number in pods. Decrease of 1000 seed weight is due to decline of water and nutrients absorption by plant and then decrease of assimilation and assimilates transport to seed. Effect drought stress on winter canola has been studied by Andersen et al. (1996); it observed that, pod number in plant, seed number in pods and seed yield were significantly decreased by drought stress while 1000 seed weight was decreased by drought stress at flowering seed filling stages. Oil percentage was decreased by drought stress it seems that, reduces of photosynthesis and assimilates remobilization reasons decrease of oil. In addition, drought stress reduces seed filling period and oil content. Results of Mendham and Buzza (1984) are agreed to our results. Champolivier and Merrien (1996) have reported obviously decrease in oil content due to drought stress at flowering stage. Biological yield was decreased affected by drought stress. Plant height and number of branches were decreased by drought subsequently biological yield was decreased. There are many reports that, late season drought stress apart from decrease of total dry matter, decreases assimilates transportation to seeds and lead to decrease harvest index (Wright, 1995; Kajdi, 1994). Oil yield was affected by drought stress and significantly decrease was observed.

Zeolite application as a soil amendment, improved water retention capacity and increased more assayed traits. Zeolite application had not significant effect on oil percentage and harvest index. Lack of significant difference between zeolite application and absence of zeolite in soil is illustrative of this fact that, enhancement of seed yield and biological yield was increased with same ratio so there was no difference between harvest indexes in upon treatments. Plant height and number of branches in plant were increased by zeolite application. It seems that, zeolite 
Tab. 1. Physical and chemical properties of soil collected from site study

\begin{tabular}{|c|c|c|c|c|c|c|c|c|c|c|}
\hline Texture & T.N.V (\%) & $\mathrm{K}(\mathrm{ppm})$ & $\mathrm{P}(\mathrm{ppm})$ & $\mathrm{N}(\%)$ & $\begin{array}{c}\text { Saturated } \\
\text { percentage }(\%)\end{array}$ & $\begin{array}{c}\text { Organic } \\
\text { Carbon (\%) }\end{array}$ & $\mathrm{pH}$ & $\begin{array}{c}\text { EC } \\
\left(\mathrm{ds} \cdot \mathrm{m}^{-1}\right)\end{array}$ & $\begin{array}{l}\text { Depth } \\
(\mathrm{cm})\end{array}$ & Year \\
\hline \multirow{2}{*}{ Clay loam } & 8.25 & 171 & 4.9 & 0.05 & 30.58 & 0.47 & 7.8 & 1.36 & $0-30$ & \multirow{2}{*}{2006} \\
\hline & 10.69 & 132 & 2 & 0.04 & 30.84 & 0.35 & 7.7 & 1.76 & $30-60$ & \\
\hline \multirow{2}{*}{ Clay loam } & 9.81 & 205 & 3.1 & 0.06 & 36.01 & 0.51 & 7.8 & 1.42 & $0-30$ & \multirow{2}{*}{2007} \\
\hline & 10.53 & 150 & 2 & 0.06 & 37.12 & 0.40 & 7.9 & 1.44 & $30-60$ & \\
\hline
\end{tabular}

Tab. 2. Summary of combined F significance from analysis of variance of irrigation, zeolite, selenium and cultivar in 2006 and 2007

\begin{tabular}{|c|c|c|c|c|c|c|c|c|c|c|c|}
\hline O.Y & H.I & B.Y & O.P & S.Y & S.W & N.S & N.P & N.B & P.H & $\mathrm{df}$ & S.O.V \\
\hline ** & ns & $* *$ & $* *$ & ** & $*$ & ** & * & ns & $* *$ & 1 & $\mathrm{Y}$ \\
\hline ns & ns & ns & ns & ns & ns & ns & ns & ns & ns & 4 & $\mathrm{R}(\mathrm{Y})$ \\
\hline$* *$ & $* *$ & $* *$ & $* *$ & ** & $* *$ & $* *$ & $* *$ & $* *$ & $* *$ & 1 & I \\
\hline ** & $* *$ & $* *$ & ns & $* *$ & ns & ** & ** & ns & $*$ & 2 & S \\
\hline ** & ns & $* *$ & ns & $* *$ & $* *$ & $* *$ & ** & $* *$ & $* *$ & 1 & $\mathrm{Z}$ \\
\hline$* *$ & ns & $* *$ & ns & $* *$ & ns & * & $* *$ & ns & ns & 2 & $I^{*} S$ \\
\hline$* *$ & ns & $* *$ & ns & $* *$ & ns & ns & ns & ns & ns & 1 & $I^{*} Z$ \\
\hline ns & ns & $*$ & $*$ & $* *$ & ns & ns & ns & ns & ns & 1 & $\mathrm{I}^{*} \mathrm{Y}$ \\
\hline ns & ns & ns & ns & ns & ns & ns & ns & ns & ns & 2 & $S^{*} Y$ \\
\hline ns & ns & ns & ns & ns & ns & ns & ns & ns & ns & 1 & $\mathrm{Z}^{*} \mathrm{Y}$ \\
\hline$* *$ & $* *$ & ns & $*$ & $* *$ & ns & ns & ns & ns & ns & 2 & $\mathrm{~S}^{*} \mathrm{Z}$ \\
\hline$* *$ & $*$ & $* *$ & ns & $* *$ & ns & ns & $*$ & ns & ns & 2 & $\mathrm{I}^{*} \mathrm{~S}^{*} \mathrm{Z}$ \\
\hline ns & ns & ns & $*$ & ns & ns & ns & ns & ns & ns & 2 & $\mathrm{I}^{*} \mathrm{~S}^{*} \mathrm{Y}$ \\
\hline ns & ns & ns & $* *$ & ns & ns & ns & ns & ns & ns & 1 & $\mathrm{I}^{*} \mathrm{Z}^{*} \mathrm{Y}$ \\
\hline ns & ns & ns & ns & ns & ns & ns & ns & ns & ns & 2 & $S^{*} Z^{*} Y$ \\
\hline ns & ns & ns & ns & ns & ns & ns & ns & ns & ns & 2 & $\mathrm{I}^{*} \mathrm{~S}^{*} \mathrm{Z}^{*} \mathrm{Y}$ \\
\hline ns & ns & ns & ns & ns & ns & ns & ns & ns & ns & 44 & $\mathrm{R}^{*} \mathrm{I}^{*} \mathrm{~S}^{*} \mathrm{Z}(\mathrm{Y})$ \\
\hline$* *$ & $* *$ & $* *$ & $*$ & $* *$ & $* *$ & $* *$ & $* *$ & $* *$ & ** & 2 & C \\
\hline ns & ns & ns & $* *$ & ns & * & $* *$ & $* *$ & ns & $*$ & 2 & $\mathrm{I}^{*} \mathrm{C}$ \\
\hline$* *$ & $* *$ & $* *$ & ns & ** & ns & ns & ns & ns & ns & 4 & $\mathrm{~S}^{*} \mathrm{C}$ \\
\hline$* *$ & $* *$ & $* *$ & ns & $* *$ & ns & ns & * & ns & ns & 2 & $\mathrm{Z}^{*} \mathrm{C}$ \\
\hline ns & ns & ns & ns & $\mathrm{ns}$ & ns & ns & ns & ns & $\mathrm{ns}$ & 2 & $\mathrm{C}^{*} \mathrm{Y}$ \\
\hline ns & ns & ns & ns & ns & ns & ns & ns & ns & ns & 2 & $\mathrm{I}^{*} \mathrm{C}^{*} \mathrm{Y}$ \\
\hline ns & ns & ns & ns & ns & ns & ns & ns & ns & ns & 4 & $\mathrm{~S}^{*} \mathrm{C}^{*} \mathrm{Y}$ \\
\hline ns & ns & ns & ** & ns & ns & ns & ns & ns & ns & 2 & $\mathrm{Z}^{*} \mathrm{C}^{*} \mathrm{Y}$ \\
\hline ns & $* *$ & $* *$ & ns & ns & ns & ns & ns & ns & ns & 4 & $\mathrm{I}^{*} \mathrm{~S}^{*} \mathrm{C}$ \\
\hline ns & ** & $* *$ & ns & ns & ns & ns & ns & ns & ns & 4 & $\mathrm{~S}^{*} \mathrm{Z}^{*} \mathrm{C}$ \\
\hline * & $* *$ & ns & $*$ & $*$ & ns & ns & ns & ns & ns & 2 & $\mathrm{I}^{*} \mathrm{Z}^{*} \mathrm{C}$ \\
\hline ns & ns & ns & ns & ns & ns & ns & ns & ns & ns & 4 & $\mathrm{I}^{*} \mathrm{~S}^{*} \mathrm{C}^{*} \mathrm{Y}$ \\
\hline$* *$ & ** & ** & ns & $* *$ & $\mathrm{~ns}$ & ns & ns & ns & ns & 4 & $\mathrm{I}^{*} \mathrm{~S}^{*} \mathrm{Z}^{*} \mathrm{C}$ \\
\hline ns & ns & ns & ns & ns & ns & ns & ns & ns & ns & 4 & $\mathrm{~S}^{*} \mathrm{Z}^{*} \mathrm{C}^{*} \mathrm{Y}$ \\
\hline ns & ns & ns & ns & ns & ns & ns & ns & ns & ns & 2 & $\mathrm{I}^{*} \mathrm{Z}^{*} \mathrm{C}^{*} \mathrm{Y}$ \\
\hline ns & ns & ns & ns & ns & ns & ns & ns & ns & ns & 4 & $\mathrm{I}^{*} \mathrm{~S}^{*} \mathrm{Z}^{*} \mathrm{C}^{*} \mathrm{Y}$ \\
\hline 11.9 & 12.6 & 8.6 & 2.2 & 11.4 & 4.8 & 9.5 & 13.2 & 24.8 & 8.2 & & C.V \\
\hline
\end{tabular}

Y: Year; I: irrigation; S: Selenium; Z: Zeolite; C: Cultivar; P.H: Plant height; N.B: Number of branches in plant; N.P: Number of pods in plant; N.S: Number of seeds in pod; S.W: 1000 seed weight; S.Y: Seed yield; O.P: Oil percentage; B.Y: Biological yield; H.I: Harvest index; O.Y: Oil yield. ns: Not significant, ${ }^{*}$ and ${ }^{* *}$ : significant at $\mathrm{P}<0.05$ and $\mathrm{P}<0.01$, respectively 
Tab. 3. Main effects of year, irrigation, zeolite, selenium and cultivar on some agronomic traits of three canola cultivar in 2006 and 2007

\begin{tabular}{|c|c|c|c|c|c|c|c|c|c|c|c|}
\hline O.Y & H.I & B.Y & O.P & S.Y & S.W & N.S & N.P & N.B & P.H & Levels & Treatments \\
\hline $1632.94 b$ & $24.24 a$ & $17717.2 \mathrm{a}$ & $43.14 a$ & $3765.29 b$ & $5.46 \mathrm{~b}$ & $22.99 \mathrm{~b}$ & $70.59 b$ & $3.16 \mathrm{a}$ & $86.54 b$ & 2006 & \multirow{2}{*}{ Year } \\
\hline $1822.89 \mathrm{a}$ & $25.29 \mathrm{a}$ & $15406.3 \mathrm{~b}$ & $40.19 b$ & $4518.29 \mathrm{a}$ & $5.68 \mathrm{a}$ & $25.17 \mathrm{a}$ & $81.26 \mathrm{a}$ & $3.42 \mathrm{a}$ & $97.76 \mathrm{a}$ & 2007 & \\
\hline $2300.23 a$ & $26.80 a$ & $20479.8 \mathrm{a}$ & $42.28 \mathrm{a}$ & $5456.33 a$ & $5.75 a$ & $26.12 \mathrm{a}$ & $90.73 a$ & $3.61 \mathrm{a}$ & $98.32 \mathrm{a}$ & Complete & \multirow{2}{*}{ Irrigation } \\
\hline $1155.60 \mathrm{~b}$ & $22.74 b$ & $12643.7 \mathrm{~b}$ & $41.05 \mathrm{~b}$ & $2827.24 b$ & $5.39 \mathrm{~b}$ & $22.04 \mathrm{~b}$ & $61.11 \mathrm{~b}$ & $2.97 \mathrm{~b}$ & $85.98 \mathrm{~b}$ & Limit & \\
\hline $1488.12 b$ & $25.06 a$ & $14116.00 \mathrm{~b}$ & $41.78 \mathrm{a}$ & $3563.13 b$ & $5.48 b$ & $23.04 b$ & $67.31 \mathrm{~b}$ & $3.11 \mathrm{~b}$ & $88.37 b$ & 0 ton.ha-1 & \multirow{2}{*}{ Zeolite } \\
\hline $196772 \mathrm{a}$ & $24.47 \mathrm{a}$ & $19007.50 \mathrm{a}$ & $41.56 \mathrm{a}$ & $4720.44 a$ & $5.66 \mathrm{a}$ & $25.12 \mathrm{a}$ & $84.54 \mathrm{a}$ & $3.47 \mathrm{a}$ & $95.93 \mathrm{a}$ & 10 ton.ha-1 & \\
\hline $1552.14 \mathrm{~b}$ & $23.23 c$ & $15590.00 \mathrm{~b}$ & $41.94 \mathrm{a}$ & $3704.92 \mathrm{c}$ & $5.51 \mathrm{a}$ & $23.23 b$ & $69.99 \mathrm{~b}$ & $3.16 \mathrm{a}$ & $90.12 b$ & 0 gr.liter-1 & \multirow{3}{*}{ Selenium } \\
\hline $1776.61 \mathrm{a}$ & $24.65 b$ & $17095.50 \mathrm{a}$ & $41.9 \mathrm{ab}$ & $4263.17 b$ & $5.61 \mathrm{a}$ & $64.24 a$ & $78.94 a$ & $3.35 a$ & $93.32 \mathrm{a}$ & 15 gr.liter-1 & \\
\hline $1855.00 \mathrm{a}$ & $26.43 a$ & $16999.70 \mathrm{a}$ & $41.47 \mathrm{~b}$ & $4457.28 \mathrm{a}$ & $5.58 \mathrm{a}$ & $24.37 \mathrm{a}$ & $78.83 \mathrm{a}$ & $3.36 \mathrm{a}$ & $93.01 \mathrm{a}$ & 30 gr.liter-1 & \\
\hline $1654.04 b$ & $25.27 \mathrm{a}$ & $15478.00 \mathrm{~b}$ & $41.84 \mathrm{a}$ & $3941.68 b$ & $5.60 \mathrm{~b}$ & $21.20 \mathrm{c}$ & $94.28 \mathrm{a}$ & $3.95 a$ & $86.69 \mathrm{c}$ & 'Sarigol' & \multirow{3}{*}{ Cultivar } \\
\hline $1777.65 \mathrm{a}$ & $22.80 \mathrm{~b}$ & $18308.60 \mathrm{a}$ & $41.44 b$ & $4275.25 a$ & $5.77 \mathrm{a}$ & $24.99 \mathrm{~b}$ & $71.31 \mathrm{~b}$ & $3.02 b$ & $99.56 \mathrm{a}$ & 'Zarfam' & \\
\hline $1752.06 \mathrm{a}$ & $26.23 \mathrm{a}$ & $15898.60 \mathrm{~b}$ & $41.73 \mathrm{ab}$ & $4208.43 a$ & $5.33 c$ & $26.05 \mathrm{a}$ & $62.18 \mathrm{c}$ & $2.90 \mathrm{~b}$ & $90.20 \mathrm{~b}$ & 'Okapi' & \\
\hline
\end{tabular}

P.H: Plant height; N.B: Number of branches in plant; N.P: Number of pods in plant; N.S: Number of seeds in pod; S.W: 1000 seed weight; S.Y: Seed yield; O.P: Oil percentage; B.Y: Biological yield; H.I: Harvest index; O.Y: Oil yield. For a given means within each column of each section followed by the same letter are not significantly different $(\mathrm{p}<0.05)$.

improved soil cation exchangeable capacity and so water and nutrients were accessible for canola plants. Increase of canola plant height has been reported due to nitrogen availability (Ozer, 2003). Positive effect of zeolite on plant height, number of branches, yield and yield component can be related to increment of nitrogen availability and prevent of nitrogen leaching. Similar these results are reported by Sing and Bhargava (1994). Also increase of biological yield is associated with water and nutrition availability.

In general, selenium foliar application had positive effect on most traits. This treatment had not significant effect on number of branches in plant, 1000 seed weight and oil percentage. It's reported that, selenium has antioxidant properties and under conditions of environmental stress especially water stress it can scavenge reactive oxygen species (Xue et al., 2001). Glutathione peroxidase is an important enzyme in antioxidant defense system of plants. Selenium is an essential element in structure of this enzyme. In this study seed yield was increased by selenium application due to enhancement of pod number in plant and seed number in pods. It seems that, selenium improved pollen survival and fertilization. Also it's reported that, selenium prevents from chlorophyll degradation under stress conditions (Seppänen et al., 2003). Enhancement of photosynthesis and decrease of leaf senescence (Xue and Hartikaine, 2001) increases assimilate production and transportation toward seeds and as a result seed yield will be increased. Tab. 3 shows that, canola cultivars are different from each other in respect of height, number of pods in plant, number of seeds in pod and 1000 seed weight. The highest seed yield and oil yield was related Zerfam and 'Okapi' cultivars while the highest oil percentage was obtained from 'Sarigol' and 'Okapi' cultivars. These differences can be associated to genetic background of these cultivars. Comparison of means among different canola cultivars under different irrigation treatments, zeolite and selenium foliar application are shown in Tab. 4. Comparisons of means were performed by LSMEANS command in SAS software so these comparisons were done among different canola cultivars under different treatment condition. There was not significant different among canola cultivars on seed yield under completed irrigation, no zeolite and selenium while the highest biological yield was related to Zerfam. The highest harvest index and the lowest oil yield were obtained from 'Sarigol' and 'Okapi', respectively. There was not significant difference between oil yield of Zerfam and 'Sarigol'.

Also under conditions of completed irrigation, zeolite application there was not difference among cultivars in respect of seed yield, biological yield, harvest index and oil yield.

It observed that, the highest harvest index was achieved from 'Okapi' and 'Sarigol' under complete irrigation and $15 \mathrm{mg}$.liter ${ }^{-1}$ selenium treatments. Respect of other traits there was not significant difference among cultivars.

Under completed irrigation and zeolite application treatments, foliar application by $15 \mathrm{mg}^{-1 i t e r^{-1}}$ selenium showed that there was not different among seed yield and biological yield of cultivars. But the lowest harvest index and oil yield was obtained from 'Sarigol' while between Zerfam and 'Okapi' was not significant difference.

Foliar application with $30 \mathrm{mg}^{-1 i t e r^{-1}}$ selenium under conditions of completed irrigation and lack of zeolite showed that there are not significant differences among cultivars of seed yield, harvest index and oil yield while biological yield was increased in 'Zarfam' than other cultivars. In contrast the highest seed yield and oil yield was obtained from 'Okapi' and 'Zarfam' under conditions of completed irrigation, zeolite use and $30 \mathrm{mg}^{-1 i t e r}{ }^{-1}$ selenium foliar application. Also the highest of biological yield 
78

Tab. 4. Effects of irrigation, zeolite and selenium treatments on seed yield, biological yield, harvest index and oil yield three canola cultivar in 2006 and 2007

\begin{tabular}{|c|c|c|c|c|c|}
\hline Oil yield & Harvest index & Biological yield & Seed yield & Cultivar & \\
\hline $1799.2 \mathrm{a}$ & $22.58 b$ & $18813 \mathrm{a}$ & $4277.8 \mathrm{a}$ & 'Zarfam' & \multirow{3}{*}{ IIS1Z1 } \\
\hline $1463.5 b$ & $22.71 b$ & $15528 \mathrm{~b}$ & $3521.7 \mathrm{a}$ & 'Okapi' & \\
\hline $1799.2 \mathrm{a}$ & $2827 \mathrm{a}$ & $15229 \mathrm{~b}$ & $4300.8 \mathrm{a}$ & 'Sarigol' & \\
\hline $2537.2 \mathrm{a}$ & $27.87 \mathrm{a}$ & $21201 \mathrm{a}$ & $5915.7 \mathrm{a}$ & 'Zarfam' & \multirow{3}{*}{ I1S1Z2 } \\
\hline $2347.1 \mathrm{a}$ & $25.98 \mathrm{a}$ & $21799 a$ & $5637.7 \mathrm{a}$ & 'Okapi' & \\
\hline $2344.0 \mathrm{a}$ & $25.41 \mathrm{a}$ & $22097 \mathrm{a}$ & $5584.0 \mathrm{a}$ & 'Sarigol' & \\
\hline $2042.6 a$ & $19111 \mathrm{a}$ & $25.29 \mathrm{~b}$ & $4827.8 \mathrm{a}$ & 'Zarfam' & \multirow{3}{*}{ IlS2Z1 } \\
\hline $2116.8 \mathrm{a}$ & $16424 a$ & $30.32 \mathrm{a}$ & $4980.5 \mathrm{a}$ & 'Okapi' & \\
\hline $1958.2 \mathrm{a}$ & $15826 a$ & $28.71 \mathrm{a}$ & $4522.2 \mathrm{a}$ & 'Sarigol' & \\
\hline $2761.3 a$ & $27.76 a$ & $23740 a$ & $6615.3 a$ & 'Zarfam' & \multirow{3}{*}{ I1S2Z2 } \\
\hline $2657.4 \mathrm{ab}$ & $27.34 \mathrm{a}$ & $23590 \mathrm{a}$ & $6386.3 a$ & 'Okapi' & \\
\hline $2380.9 b$ & $23.71 b$ & $23292 a$ & $5599.3 \mathrm{a}$ & 'Sarigol' & \\
\hline $2112.3 \mathrm{a}$ & $25.81 \mathrm{a}$ & $19858 \mathrm{a}$ & $5079.8 \mathrm{a}$ & 'Zarfam' & \multirow{3}{*}{ I1S3Z1 } \\
\hline 2093.1a & $29.47 \mathrm{a}$ & $17320 \mathrm{~b}$ & $5125.7 \mathrm{a}$ & 'Okapi' & \\
\hline $2139.3 a$ & $27.11 \mathrm{a}$ & $18812 \mathrm{ab}$ & $5064.7 a$ & 'Sarigol' & \\
\hline $3057.1 \mathrm{a}$ & $23.01 b$ & $31205 a$ & $7180.5 a$ & 'Zarfam' & \multirow{3}{*}{ I1S3Z2 } \\
\hline $3196.3 a$ & $30.25 \mathrm{a}$ & $25083 b$ & $7585.3 \mathrm{a}$ & 'Okapi' & \\
\hline $2568.8 b$ & $30.77 \mathrm{a}$ & $19708 \mathrm{c}$ & $6011.8 b$ & 'Sarigol' & \\
\hline $656.1 \mathrm{~b}$ & $14.80 \mathrm{c}$ & $10750.0 \mathrm{a}$ & $1588.8 \mathrm{~b}$ & 'Zarfam' & \multirow{3}{*}{$\mathrm{I} 2 \mathrm{~S} 1 \mathrm{Z1}$} \\
\hline $712.1 \mathrm{~b}$ & $20.73 b$ & $8062.5 c$ & $1680.7 b$ & 'Okapi' & \\
\hline $945.9 a$ & $24.61 \mathrm{a}$ & $9257.0 \mathrm{~b}$ & $2276.3 a$ & 'Sarigol' & \\
\hline $1377.7 \mathrm{a}$ & $20.88 \mathrm{a}$ & $16125.0 \mathrm{a}$ & $3368.8 \mathrm{a}$ & 'Zarfam' & \multirow{3}{*}{$\mathrm{I} 2 \mathrm{~S} 1 \mathrm{Z} 2$} \\
\hline $1345.7 \mathrm{a}$ & $22.21 \mathrm{a}$ & $14631.7 \mathrm{ab}$ & $3246.5 \mathrm{a}$ & 'Okapi' & \\
\hline $1266.8 \mathrm{a}$ & $22.73 a$ & $13586.8 \mathrm{~b}$ & $3063.2 \mathrm{a}$ & 'Sarigol' & \\
\hline $1255.8 \mathrm{a}$ & $20.71 b$ & $14632.1 \mathrm{a}$ & $3025.0 \mathrm{a}$ & 'Zarfam' & \multirow{3}{*}{$\mathrm{I} 2 \mathrm{~S} 2 \mathrm{Z} 1$} \\
\hline $1076.3 b$ & $23.58 \mathrm{a}$ & $11048.6 b$ & $2612.5 \mathrm{a}$ & 'Okapi' & \\
\hline $1059.6 \mathrm{~b}$ & $22.68 \mathrm{ab}$ & $11496.6 \mathrm{~b}$ & $2620.2 \mathrm{a}$ & 'Sarigol' & \\
\hline $1364.7 \mathrm{a}$ & $21.06 \mathrm{a}$ & $16573.0 \mathrm{a}$ & $3437.5 a$ & 'Zarfam' & \multirow{3}{*}{$\mathrm{I} 2 \mathrm{~S} 2 \mathrm{Z} 2$} \\
\hline $1379.0 \mathrm{a}$ & $21.90 \mathrm{a}$ & $15379.0 \mathrm{ab}$ & $3368.8 \mathrm{a}$ & ‘Okapi’ & \\
\hline $1266.5 \mathrm{a}$ & $22.70 \mathrm{a}$ & $14035.0 \mathrm{~b}$ & $3162.5 \mathrm{a}$ & 'Sarigol' & \\
\hline $1118.4 b$ & $23.02 b$ & $12243.0 \mathrm{a}$ & $2803.3 \mathrm{ab}$ & 'Zarfam' & \multirow{3}{*}{$\mathrm{I} 2 \mathrm{~S} 3 \mathrm{Z} 1$} \\
\hline $1446.6 a$ & $38.02 \mathrm{a}$ & $9227.0 \mathrm{~b}$ & $3468.0 \mathrm{a}$ & 'Okapi' & \\
\hline $960.9 \mathrm{~b}$ & $22.71 \mathrm{~b}$ & $10451.0 \mathrm{ab}$ & $2360.5 b$ & 'Sarigol' & \\
\hline $1249.3 a$ & $20.85 a$ & $15453.0 \mathrm{a}$ & $3158.5 a$ & 'Zarfam' & \multirow{3}{*}{$\mathrm{I} 2 \mathrm{~S} 3 \mathrm{Z} 2$} \\
\hline $1189.6 \mathrm{ab}$ & $22.23 a$ & $12989.7 \mathrm{~b}$ & $2887.5 \mathrm{ab}$ & 'Okapi' & \\
\hline $1128.3 \mathrm{~b}$ & $23.85 a$ & $11645.8 \mathrm{~b}$ & $2734.7 \mathrm{~b}$ & 'Sarigol' & \\
\hline
\end{tabular}

I1: complete irrigation; I2: limited irrigation at stem elongation stage; S1: 0 gr.liter-1 Selenium; S2 15 gr.liter-1 Selenium; S3: 30 gr.liter-1 Selenium; Z1: no zeolite; Z2: 10 ton.ha-1 zeolite. For a given means within each column of each section followed by the same letter are not significantly different $(\mathrm{p}<0.05)$.

was observed in 'Zarfam' cultivar. Harvest index in 'Okapi' and 'Sarigol' in this treatment was more than 'Zarfam'.

The 'Sarigol' cultivar had the highest seed yield, harvest index and oil yield under conditions of late season drought stress and without zeolite and selenium while the highest of biological yield was related to 'Zarfam'. In this condition zeolite application increased seed yield in 'Zarfam' and 'Okapi' and improved biological yield in 'Okapi'. The results showed that, harvest index and oil yield were increased by zeolite in 'Zarfam' and 'Okapi'.
There are not significant differences among cultivars in respect of seed yield under conditions of late season drought stress, lack of zeolite and $15 \mathrm{mg}$ liter $^{-1}$ selenium foliar application but in compare to $0 \mathrm{mg}^{-1 i t e r^{-1}}$ selenium (Control) seed yield was increased in 'Okapi' and 'Zarfam' cultivars. Biological yield was increased in 'Okapi' cultivar due to selenium foliar application under drought stress condition. The highest of harvest index was observed in 'Okapi' and 'Sarigol' cultivars under late season drought 
stress and $30 \mathrm{mg}$. liter $^{-1}$ selenium foliar application. Also the highest oil yield was achieved by 'Zarfam'.

There are not significant differences among cultivars in respect of seed yield, harvest index and oil yield under conditions of late season drought stress, zeolite application and $15 \mathrm{mg}$ liter $^{-1}$ selenium foliar application. It was observed that, application of $15 \mathrm{mg} .1 \mathrm{iter}^{-1}$ selenium under conditions of limited irrigation and zeolite application had not significant effect on seed yield, biological yield, oil yield and harvest index in compare to lack of selenium in similar condition.

The highest seed yield, harvest index and oil yield was obtained from 'Okapi' cultivar under conditions of limited irrigation, non zeolite application and $30 \mathrm{mg}$.liter ${ }^{-1}$ selenium foliar application while the highest of biological yield was related to 'Zarfam' cultivar. The highest and the lowest seed yield, biological yield and oil yield were achieved from 'Zarfam' and 'Sarigol' cultivars under conditions of late season drought stress, zeolite application and $30 \mathrm{mg}$. liter ${ }^{-1}$ selenium foliar application. In addition, there are not significant differences among cultivars about harvest index under upon mentioned condition.

\section{Conclusions}

In conclusion, it was observed that, under conditions of late season drought stress 'Sarigol' cultivar produced the highest seed yield, harvest index and oil yield than two other cultivars. Also the highest biological yield was related to 'Zarfam' cultivar under conditions of late season drought stress and completed irrigation and it is suitable for forage production. Zeolite application in lands which are exposure to late season drought stress can keep soil water content and improve plant growth and production. The result shows that selenium as foliar application can improve yield under conditions of drought stress and it can be suggested for these lands in arid and semi arid regions.

\section{References}

Andersen, M. N., T. Heidmann and F. Plauborg. 1996. The effect of drought and nitrogen on light compensation growth and yield of winter oil seed raps. Acta. Agri. Scandinavica. 46(1): 55-67.

Bouchereau, A., Clossais-Besnard, N., Bensaoud, A., Leport, L. and Renard, M. 1996. Water stress effects on rapeseed quality. European Journal of Agronomy 5 pp:19-30.

Champolivier,I.and A.Merrien.1996.Effects of water stress applied at different growth stages to Brassica napus L.var. Oleifera on yiled, yiled components and seed quality.Eur. J. Agron.

Deepak, M.and P.N. Wattal. 1995. Influence of water stress on seed yield of Canadian rape at flowering and role of metabolic factors. Plant physiol and Biochem. New Dehli.
22(2):115-118.

Dwairi, I.M. 1998. Evaluation of Jordanian zeolite tuff as a controlled slow-release fertilizer for NH4. Environmental Geology. 34:1-3.

Germ M., Kreft I., Osvald J. 2005. Influence of UV-B exclusion and selenium treatment on photochemical efficiency of photosystem II, yield and respiratory potential in pumpkins (Cucurbita pepo L.). Plant Physiol. Biochem., 43: 445-448.

Hashem, A., M. N. A. Majumdar, A. Hamid, M. M. Hossain. 1998. Drought stress effects on seed yield, yield attributes, growth, cell membrane stability and gas exchange of synthesized Brassica napus. J. Agron. and Crop Sci. 180(3): 129-136.

Hartikainen H., Xue T., Piironen V. 2000. Selenium as an antioxidant and pro-oxidant in ryegrass. Plant Soil, 225: 193-200.Sci., 165, 311-3192003.

He, Z.L., D.V., Calvert, A.K., Li., Y.C., and D.J., Alva-Banks. 2002. Clinoptilolite Zeolite and cellulose amendments to reduce ammonia volatilization in a calcareous sandy soil. Plant and Soil. 247:253-260.

Jensen, C. R., V. O. Mogensen, G. Mortensen, J. K. Fieldsen and G. H. Thage. 1996. Seed glocosinolate oil and protein content of field grown rape (Brassica napus L.) affected by soil drying and evaporative demand. Field Crop Res. 47:93105.

Kajdi, F. 1994. Effect of irrigation on the protein and oil content of rape varieties. Acta Agronomica. 36: 41-50.

Kuznetsov V.V., Kholodova V.P., Kuznetsov V.V., Yagodin B.A. 2003. Selenium regulates the water status of plants exposed to drought. Dokl. Biol. Sci., 390:266-268.

Liu, F., M. N. Andersen and C. R. Jensen. 2004. Root signal controls pod growth in drought stressed Soybean during the critical, abortion-sensitive phase of pod development. Field Crops Res. 85: 159-166.

Mendham, N. J., and P.A. Salisbury. 1995. Physiology: crop development, growth and yield. In: Kimber, D. and McGregor, D.I. (Eds.), Brassica oilseeds - Production and utilization, CAB, pp 11-64.

Mendham,N.J.; Russell,J.andBuzza, G.C.1984. The contribution of seed survival to field in new Australian cultivars of oilseed rape (Brassica napus L.) journal of Agricultural science. Cam bridge. 103:303-316.

Mumpton, F.A. 1999. La roca magica: Uses of natural Zeolite in agriculture and industry. Proceeding of the National Academy. 96:3463-3470.

Nowak J., Kaklewski K., Ligocki M. 2004. Influence of selenium on oxidoreductive enzymes activity in soil and in plants. Soil Biol. Biochem., 36:1553-1558.

Ok, C.H., S.H. ,Anderson and E.H., Ervin. 2003. Amendments and construction systems for improving the performance of sand-based putting greens. Agronomy Journal. 95: 15831590.

Pennanen A., Xue T., Hartikainen H. 2002. Protective role of 
80

selenium in plant subjected to severe UV irridiation stress. J. Appl. Bot., 76: 66-76.

Rao, M.S.S., and N.J.Mendham. 1991. Comarision of chinoli (B.compestris. Subs. Oleifera, Subsp. Chinesis) and B.napus Oilseed Rape Using Different Growth Regulators, Plant Population, Denisties and Irrigation treatments. J.Agric sci. Camb. 177:177-178.

Rehakova, M., S.,Cuvanova, M., Dzivak, J., Rimarand, and Z., Gavalova. 2004. Agricultural and agrochemical uses of natural zeolite of the clinoptilolite type. Current Opinion in Soil State and Materials Science. 8: 397-404.

Seppänen, M.,M. Turakainen and H. Hartikainen, Selenium effects on oxidative stress in potato.

Sing, H.C., and S.C., Bhargava. 1994. Changes in growth and yield components of Brassica napus in response to azotobacter inoculation at different rates of nitrogen application. Journal of Agriculture Science. 122:241-247.

Tapiero H., Townsend D.M., Tew K.D. 2003. Dossier: Oxidative stress pathologies and antioxidants: The antioxidant role of selenium and seleno-compounds. Biomed. Pharmacoth., 57: 134-144,
Thomas, M., J. Robertson, S. Fukai and M. B. Peoples. 2004. The effect of timing and severity of water dificit on growth, development, yield accumulation and nitrogen fixation of mungbean. Field Crops Res. 86: 67-80.

Triboi- Blondel, A. M., and M. Renard. 1999. Effect of temperature and stress of fatty acid composition of rapeseed oil. 10 ${ }^{\text {th }}$. International Rapeseed Congress. Australia.

Wright, G.C., Smith, C.J. and Woodroofe, M.R., 1988. The effect of irrigation and nitrogen fertilizer on rapeseed (Brassica napus) production in south-eastern Australia. Irrig. Sci., 9: 1-13.

Wright, P. R., J. M. Morgan, R. S. Jossop and A. Cass. 1995. Comparative adaptation of canola (Brassica napus L.) and indian mustard (Brassica Juncea) to soil water deficit. Field Crop Res. 42: 1-13.

Xue T.L., Hartikainen H., Piironen V. 2001. Antioxidative and growth-promoting effects of selenium on senescing lettuce. Plant Soil, 237: 55-61. 